\title{
ANIMAL ETHICS THEORIES: THE CURRENT DEBATE
}

\author{
Jéssica Lauren Steffen ${ }^{1}$
}

Carolina Klanovicz de Araújo

\section{INTRODUCTION}

On the morning of October 18, 2013, about a hundred activists stormed the headquarters of the Royal Institute in São Roque (São Paulo), Brazil. On the grounds that the institution, responsible for conducting tests for pharmaceutical companies, was subjecting animals to mistreatment. Facilities were ravaged and cages were forced open, so that around 178 beagle dogs were rescued. As reported by the invaders, six of the dogs had tumors and presented mutilations ${ }^{3}$. According to the Royal Institute, "animals must always be held in the best living conditions and health." In addition, statements were released claiming that cancer research had been hampered, while classifying the incident as a terrorist act ${ }^{4}$.

\footnotetext{
${ }^{1}$ Jurist from the Pontifical Catholic University of Rio Grande do Sul- 2014 (Brazil). Currently scholarship student of the Master in Animal Law and Society at the Autonomous University of Barcelona (Spain). Member of the Laboratory of Bioethics and Ethics Applied to Animals of the Pontifical Catholic University of Rio Grande do Sul (Brazil). Member of the ADS research at the Autonomous University of Barcelona (Spain).

${ }^{2}$ Jurist from the Pontifical Catholic University of Rio Grande do Sul- 2014 (Brazil). Lawyer, member of the Brazilian Bar Association (OAB - Ordem dos Advogados do Brasil, in portuguese) .

${ }^{3}$ ALVES, MARTHA (2013). Ativistas resgatam cães de laboratório de testes em São Roque. Folha de S. Paulo, 18 Oct. 2013. Available at <http://www1.folha.uol.com.br/cotidiano/2013/10/1358477-ativistas-invadem-laboratorio-emsao-roque.shtml>. Access on 16 Oct. 2014.

${ }^{4}$ FALCÃO, Márcio. (2013) Retirada de beagles de instituto foi ato 'fora da lei'. Folha de S. Paulo, 23 Oct. 2013. Available at <http://www1.folha.uol.com.br/cotidiano/2013/10/1360890retirada-de-beagles-de-instituto-foi-ato-fora-da-lei-diz-ministro.shtml>. Access on 16 Oct. 2014.
} 
The case had great resonance in the national and international media. The coordinator of the National Council for Animal Experiments Control in Brazil (CONCEA) at the time - who was also a board member of the private entity the Brazilian Society for the Progress of Science (SBPC) - reported that the this lab "backed up the self-support of Brazil about new drugs" and, because of what happened, "millions of reals were thrown away, and years of research for the benefit of the Brazilian people and animals were also lost" ${ }^{\text {}}$. In an official statement, the CONCEA affirmed that not only the Royal Institute was regularly registered within the agency, but its performance was in full compliance with the legal requirements for the use of animals in science ${ }^{6}$.

From this perspective it is possible to catch a glimpse of both the awakening of Brazilian citizens with regard to the issue of animal testing, as this was the first activist action of this kind to take place in Brazil, and also realize the serious importance of the problem with which we are dealing.

\section{ANIMAL ETHICS}

Consequent to the awakening of society with regard to the treatment of animals, it is increasingly possible to observe and consider studies related to how animals should be treated and what is their status as living beings. All this progress leads us to a very important point in such a reflection: our use of nonhuman animals and the research for ethically appropriate attitudes in this context.

Among the various philosophical theories dealing with the animal condition, the following will be synthetically presented: the one of animal welfare and the one of animal rights, being the best known and those that have guided

\footnotetext{
${ }^{5}$ CRUZ, Fernanda (2013). Beagles do Instituto Royal não sofriam maus-tratos. Agência Brasil, 22 Oct. 2013. Available at <http://www.ebc.com.br/noticias/brasil/2013/10/caes-retirados-doinstituto-royal-nao-sofriam-maus-tratos-diz-coordenador-do>. Access on 16 Oct. 2014.

${ }^{6}$ AGÊNCIA BRASIL (2013). Instituto Royal pode utilizar animais em pesquisa, diz ministério. Portal EBC,18 Oct. 2013. Available at <http://www.ebc.com.br/cidadania/2013/10/ministerio-dizque-instituto-royal-pode-utilizar-animais-para-pesquisa>. Access on 16 Oct. 2014.
} 
the current debates. According to Naconecy (2006, p. 39-40): "The role of ethical theories is to guide our actions and direct our attitudes through moral judgments. A moral judgment is justified when it is supported by good reasons"'.

An ethical theory is an attempt to answer the question whether we are acting ethically or not, and to justify a decision. Naconecy ${ }^{8}$ identifies two types of theories: consequentialism and non-consequentialism. While the formulations from the first group classify a correct action as the one able to cause positive results and prevent the negative, those from the second group assume that, whatever the outcome, some actions are necessary.

Utilitarianism, which is the main variant of consequentialism, alleges that "the right action is the one that is likely to result in the greatest possible amount of well-being (happiness or utility) to the largest possible number of the involved" ${ }^{9}$ (NACONECY, 2006: pg. 49). And, as the main variant of nonconsequentialism, we find the theory of rights, according to which "if it is true that $A$ has a (moral) right to $X$, then it is wrong to deprive $A$ of $X$, or prevent them to do $X$. If $A$ has a right to do or have $X$, then someone has an obligation to provide $A$ with $X^{110}$ (NACONECY, 2006, p. 49). Because of this emphasis on the concept of duty (obligations), the theory of rights is also defined as "deontology".

Both theories ascribe moral status to animals, which is the degree/intensity of the importance of the moral or material criterion of

\footnotetext{
${ }^{7}$ Translation by the author. Original text in Portuguese: "A função das teorias éticas é guiar nossas ações e orientar nossas atitudes por meio de juízos morais. Um juízo moral estará justificado quando ele estiver apoiado em boas razões".

${ }^{8}$ Ibidem.

${ }^{9}$ Translation by the author. Original text in Portuguese: "a ação correta é aquela que resulta provavelmente na maior quantidade possível de bem-estar (felicidade ou utilidade) para o maior número possível de envolvidos".

${ }^{10}$ Translation by the author. Original text in Portuguese: "se é verdade que $A$ tem um direito (moral) à $X$, então é errado privar $A$ de $X$, ou impedir que $A$ faça $X$. Se $A$ tem um direito a fazer ou ter $X$, então alguém tem uma obrigação de fornecer $X$ à $A$ "
} 
considerability, since the moral value is used in ethics as a synonym for a noninstrumental value. Something has instrumental value when it is a means to another end, while something has a moral, intrinsic value, when it is an end in itself. According to Naconecy ${ }^{11}$ :

Animal ethics assigns moral value to the lives of animals and/or to the states that animals experience. This value requires us to (or generates a duty to) treat animals with respect, as this value is independent from the utility or the appreciation of the animal by humans. An ethicist can also understand that this value confers dignity to the animal, a dignity that deserves to be respected by us ${ }^{12}$.

\section{Animal Welfare}

Peter Singer, in his book Animal Liberation, argues that moral equality must be understood as a prescriptive principle: we should impartially consider the interests of those affected by our actions. Excluding the interests of nonhuman animals from such consideration, or assigning them a lower weight than that we confer to similar interests of the members of our species, results unacceptably arbitrary.

Accordingly, the author (SINGER, 2010, p.10) affirms "equality is a moral idea, is not a simple assertion of fact," that is, "the defense of equality does not depend on intelligence, moral capacity or similar matters of fact". Singer moreover states that:

The extension of the basic principle of equality from one group to another does not imply that we must treat them the same way, or grant them exactly the same rights. Whether we should do so will depend on the nature of the members of the two groups. The basic principle of equality, I shall argue, is equality of consideration; and equal

\footnotetext{
${ }^{11}$ NACONECY, Carlos M.. Ética \& Animais: um guia de argumentação filosófica. Porto Alegre: Edipucrs, 2006, p. 62.

${ }^{12}$ Translation by the author. Original text in Portuguese: "A ética animal atribui valor moral à vida dos animais e/ou aos estados que os animais experienciam. Esse valor nos obriga à (ou gera um dever de) tratar os animais com o devido respeito, já que esse valor independe que o animal seja útil ou apreciado pelos humanos. Um eticista pode entender também que esse valor confere dignidade a um animal, dignidade esta que merece ser por nós respeitada".
} 
consideration for different beings may lead to different treatment and different rights. ${ }^{13}$

The arbitrary discrimination of nonhuman animals portrays what Singer calls speciesism, a term coined by Richard Ryder - in analogy with racism and sexism - which is "a prejudice or attitude of bias in favor of the interests of members of one's own species and against those of members of other species". Singer also claims that conducting experiments, such as drug testing, on a human being, would be considered incorrect, immoral, and would generate outrage. Thus, he asks: why do it on a dog? The scholar believes this to occur because we ascribe less value to non-human species, which takes form of "speciesism". According to SINGER ${ }^{14}$.

Most human beings are speciesist. Ordinary human beings not a few exceptionally cruel or heartless humans, but the overwhelming majority of humans - take an active part in, acquiesce in, and allow their taxes to pay for practices that require the sacrifice of the most important interests of members of other species in order to promote the most trivial interests of their own species.

Another issue which the author raises is that there is no guarantee that the drug or substance tested on animals has the same effect in humans. Singer highlights:

As well as exposing people to harm, testing on animals may lead us to miss out on valuable products that are dangerous to animals but not to human beings. Insulin can produce deformities in infant rabbits and mice, but not in humans. Morphine, which is calming to human beings, causes mice to go into drug frenzies. ${ }^{15}$

\footnotetext{
${ }^{13}$ SINGER, Peter. Libertação Animal. São Paulo: Editora WMF Martins Fontes, 2010, p. 5. It appears worthwhile to quote an excerpt of the work to exemplify the previously explained formulation: "Many feminists hold that women have the right to an abortion on request. It does not follow that since these same people are campaigning for equality between men and women they must support the right of men to have abortions too. Since a man cannot have an abortion, it is meaningless to talk of his right to have one. Since a dog can't vote, it is meaningless to talk of its right to vote".

${ }^{14}$ SINGER, Peter. Animal liberation. New York: Random House, 1990. p.11.

${ }^{15}$ Ibidem, p. 84.
} 


\author{
Still, there is a consideration on how scientists see animals, if a \\ relationship of respect and moral consideration exists or not. Bonella notes \\ (2009, p. 512.):
}

\begin{abstract}
Almost no scientist sees the premature and unintentional death of his "guinea pigs" as a serious problem. Vertebrate animals used in science can feel pain, stress and fear. They may also be aware of the world around them and be interested in their own life. This is what science itself teaches us, but we do not need a lot of sophisticated information to know that (at least in the case of those born mammals). And beings that can suffer frustrations and experience the world from their subjective point of view have interests as us humans; They deserve the respect due to any patient who may also suffer and have a personal life. ${ }^{16}$
\end{abstract}

Jeremy Bentham, classic utilitarian philosopher, defends the human duty of compassion for all beings vulnerable to pain and suffering. Bentham ${ }^{17}$ identifies the capacity for suffering as the characteristic that assigns a being the right to equal consideration:

The day may come when the rest of the animal creation may acquire those rights which never could have been withholden from them but by the hand of tyranny. The French have already discovered that the blackness of the skin is no reason why a human being should be abandoned without redress to the caprice of a tormentor. It may one day come to be recognised that the number of the legs, the villosity of the skin, or the termination of the os sacrum, are reasons equally insufficient for abandoning a sensitive being to the same fate. What else is it that should trace the insuperable line? Is it the faculty of reason, or perhaps the faculty of discourse? But a full-grown horse or dog is beyond comparison a more rational, as well as a more conversable animal, than an infant of a day, or a week, or even a month, old. But suppose they were otherwise, what would it avail? The question is not, Can they reason? nor Can they talk? but, Can they suffer? ${ }^{18}$

\footnotetext{
${ }^{16}$ Translation by the author. Original text in Portuguese: "Quase nenhum cientista vê a morte prematura e intencional de suas cobaias como um problema sério. Os animais vertebrados usados pela ciência podem sentir dor, estresse e medo. Eles também podem ter consciência do mundo ao seu redor e interessar-se pela sua própria vida. Isso é o que a própria ciência nos ensina, mas não precisamos de muita informação sofisticada para saber disso (ao menos no caso dos mamíferos nascidos). E seres que podem sofrer frustrações e experimentar o mundo do seu ponto de vista subjetivo têm interesses como nós, humanos; merecem o respeito devido a qualquer paciente, que também pode sofrer e ter uma vida pessoal".

17 BENTHAM, Jeremy apud SINGER, Peter.Libertação Animal. São Paulo. Editora WMF

Martins Fontes, 2010.

${ }^{18}$ Ibidem, p. 12.
} 
On the basis of the formulations made by Bentham (founder of the reformist-utilitarian school), Singer affirms that the characteristic that gives a being the right to equal moral consideration is the vital capacity to suffer, not the faculty of reason or language. If a being suffers, there is no moral justification for refusing to take into account its suffering, and similarly "there can be no moral justification for regarding the pain (or pleasure) that animals feel as less important than the same amount of pain (or pleasure) felt by humans" (SINGER, 2010, p. 24).

Singer also points out that "pain and suffering are in themselves bad and should be avoided or minimized, regardless of ethnicity, gender or species of the being that suffers" (SINGER, 2010, p. 27). In the face of such a finding it is up to man to include nonhuman animals in their sphere of moral concern.

Still, it's worth noting that the rejection of speciesism does not presume that we should treat all animals with the same consideration, regardless of their species. What it argues is that differences in treatment may never be justified simply by the belonging or not to a particular species. That is, if we consider acceptable the infliction of a certain wrong to a cow, a wrong that would be unacceptable if inflicted to a human being, we cannot justify our argument only on the grounds that the cow does not belong to the human species.

It can be said that the landmark for the recognition of dignity or intrinsic value to a particular living being is in their ability to feel pain, which occurs due to the development of the central nervous system, a characteristic of the vertebrates. According to Singer (2010, p. 14), "the limit of sentience is the only defensible boundary of concern for the interests of others". Sentience is a neologism formed by the junction of the terms sensitivity and awareness. According to Naconecy: ${ }^{19}$

(i) To say that an animal is sentient means that this animal (a) has the ability to sense, and (b) that he cares about how he feels. "To care for" means the ability to experience (subjective) satisfaction or frustration.

\footnotetext{
${ }^{19}$ NACONECY, Carlos M. Ética \& animais: um guia de argumentação filosófica. Porto Alegre: EDIPUCRS, 2006, p. 117.
} 
(ii) In Animal Ethics in particular, to say that an animal is sentient is to say that the animal is (a) able to feel pain and (b) want it to end. [...]

(v) Sentient animals interpret the sensations and information they receive from the environment through cognition (reason) and emotions. Sentience, however, is a more emotional than cognitive reaction to sensations. This causes the animal to feel, among other things, affection for their offspring, fear of being attacked, disgust for boredom and dislike of isolation. ${ }^{20}$

Feijó holds physiological sensitivity as a criterion for morality, based on the identification of specialized receptors (nociceptors) that make a being sentient. "The pain or the feeling aimed at the animal's protection, is produced by a stimulus received by existing specialized receptors called nociceptors existing in all animals, except for protozoa"21 (FEIJÓ, 2005, p.17). For the scholar, this fact justifies the entry of sensible non-human animals in the same moral community pertaining to human beings.

Important to note is that the author makes a distinction between moral agents and moral patients, stating that, although both are members of the same moral community and are holders of intrinsic value, only moral agents are assigned duties. Although non-human animals are part of the moral community and have intrinsic value, they are not moral agents but moral patients "who cannot assume duties but hold basic rights that must be defended by moral

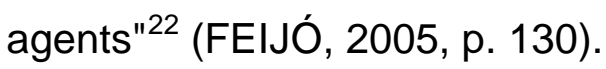

\footnotetext{
${ }^{20}$ Translation by the author. Original text in Portuguese: (i) Dizer que um animal é senciente significa dizer que esse animal (a) tem a capacidade de sentir, e (b) que ele se importa com o que sente. "Importar-se om" implica a capacidade de experimentar satisfação ou frustração (subjetiva). (ii) Para a Ética Animal em especial, dizer que um animal é senciente equivale a dizer que o animal é (a)capaz de sentir dor e (b) esejar que ela acabe. [...] (v) Animais sencientes interpretam as sensações e informações que recebem do ambiente por meio de cognição (razão) e emoções. A senciência, todavia, é uma reação mais emocional do que cognitiva às sensações. Isso faz com que um animal tenha, entre outras coisas, afeição à prole, medo de ser atacado, desgosto ao tédio e aversão ao isolamento.

${ }^{21}$ Translation by the author. Original text in Portuguese: "A dor ou a sensação que visa à proteção animal é produzida por um estímulo captado por receptores especializados chamados nociceptores existentes em todos os animais, à exceção dos protozoários".

${ }^{22}$ Translation by the author. Original text in Portuguese: "que não podem assumir deveres, mas que possuem direitos básicos que devem ser defendidos pelos agentes morais".
} 


\section{Animal Rights}

Tom Regan ${ }^{23}$, starting from a philosophical foundation of ethical matrix, supports the idea that humans and nonhuman animals are subjects of a life, which makes them equal from the moral point of view, and therefore repositories of the same respect and consideration. Thus, animals considered subjects of a life cannot be treated as mere objects, as simple means, but as protagonists of their own existence, that is, subjects of a life with an end in themselves ${ }^{24}$. The theory of animal rights has antagonistic points to the theory advocated by Peter Singer, previously presented.

The inclusion in the same species, race, ethnicity or gender does not matter in the moral discussion of whether endowing or not a being with rights or respect, but rather the simple fact that this being exists. According to Regan: "From the moral point of view, each of us is equal because each of us is equally a somebody, not a something, the subject-of-a-life, not a life without a subject" (Regan, 2006, p. 61-62). Being animals subjects of a life, as well as humans, they also have rights to life, physical integrity and freedom. For Regan, Feijó affirms, subjects of a life are "beings who have conscience, have beliefs and desires, can conceive the future and have goals" 25 (FEIJÓ, 2005, p. 103).

Regan is totally against the use of non-human animals, condemning any kind of exploitation of animals by humans, including for food and the use in science. Unlike the utilitarian view (Peter Singer's position), his theory holds that "rights enshrine what is considered fundamental for him (the individual), even if

\footnotetext{
${ }^{23}$ REGAN, Tom. Jaulas Vazias: encarando o desafio dos direitos dos animais./Tradução: Regina Rheda. Porto Alegre: Lugano, 2006.

${ }^{24}$ SARLET, Ingo Wolfgang. FENSTERSEIFER, Tiago. Direito Constitucional Ambiental. 4. ed. São Paulo: Editora Revista dos Tribunais, 2014.

${ }^{25}$ Translation by the author. Original text in Portuguese: "os seres que apresentam consciência, apresentam crenças e desejos, podem conceber o futuro e ter metas".
} 
it does not meet the social utility or it produces the least benefit for most"26 (NACONECY, 2004, p. 43). That is, animals as well as humans, have the moral right to be treated with respect, "something we fail to do every time we use our superior physical strength and general know-how to inflict harms on them in pursuit of benefits for humans" (REGAN, 1983, p. 43).

Indeed, for Regan the relationship of respect would be the synthesis of fundamental rights (life, physical integrity, freedom) which is expressed through the value of dignity, thought also to include animals. It invokes human morality to consider not only the interests of the beings of the human species, but also the interests of all beings capable of suffering pain or damage as a consequence of the actions of moral agents. According to Gordilho ${ }^{27}$ :

Moral rights are certain basic freedoms which form the core of fundamental rights, the so-called basic freedoms such as the right to life, to freedom of movement and bodily integrity, so that any violation of those rights should be seen as an affront to democratic values. ${ }^{28}$

For Jeffrey Moussaieff Masson ${ }^{29}$, Regan's philosophy is a mixture of reason and emotion, not being tied to utilitarianism or any other traditional point of view. Regan's view can be considered radical, "in the original sense of the word: to get to the root" (MASSON in COHEN \& REGAN, 2001). As per Masson, it is this treatment that allows us to say, on purely moral grounds, that there is no benefit for humanity which can make any experiment with animals less reprehensible.

\footnotetext{
${ }^{26}$ Translation by the author. Original text in Portuguese: "os direitos resguardam o que é considerado fundamental para ele (o indivíduo), mesmo que isso não atenda à utilidade social, nem produza o menor benefício para a maioria".

${ }^{27}$ GORDILHO, Heron José de Santana. Abolicionismo Animal. Salvador: Evolução, 2008. p. 74.

28 Translation by the author. Original text in Portuguese: "Direitos morais são determinadas liberdades básicas que constituem o núcleo duro dos direitos fundamentais, as denominadas liberdades básicas, como o direito à vida, à liberdade de locomoção e à integridade corporal, de modo que qualquer violação a esses direitos deve ser vista como um afronta aos valores democráticos".
}

${ }^{29}$ MASSON in COHEN, Carl. REGAN, Tom. The Animal Rights Debate. Lanham: Rowman \& Littlefield Publishers, 2001. 
Furthermore, the author affirms that one of the main contributions of Regan is proposing an update of the famous statement by Jeremy Bentham ${ }^{30}$, known as one of the most important in the movement for animal rights.

The question is not only can animals suffer but are they subjects-of-a-life? (...) Animals have a past, a story, a biography. Minks and bears, elephants and dolphins, pigs and chickens, cats and dogs: each is a unique somebody, not a disposable something. Think of the many implications: animals have mothers and fathers, often siblings, friendships, a childhood, youth, maturity. They go through life cycles much the way humans do (the psychoanalyst Erik Erikson earned his reputation by describing these phases in the lives of humans, but they are just as important in the lives of animals). (...) Opponents of Tom often say we cannot possibly know what makes an animal happy. Nonsense. Nothing could be easier. A cow wants to live, feed her young, to be outdoors in the natural world full of wind and sunshine and other natural things. ${ }^{31}$

Tom Regan is considered an advocate of animal rights, active in the movement that defends such cause. For the author, this movement is abolitionist in its aspirations. The goal is not to reform the ways in which animals are exploited, making them "more humane". The goal is to definitely end such exploitation, which would mean: abolition of commercial animal farming, abolition of the fur industry and abolition of the use of animals in science ${ }^{32}$.

The recognition of the rights of these animals has far-reaching consequences. The major animal user industries exploit these animals in billions. These are the animals whose lives are taken, whose bodies are injured, and whose freedom is denied by the fur industry and the meat industry, for example. All this emerges as morally wrong, once we acknowledge their moral rights. All this emerges as something that must be stopped, and not made more "humane". The task facing Animal Rights Activists is daunting: we must empty the cages, do make them larger. ${ }^{33}$

That's why, even considering that the use of animals in scientific experiments, for example, has undoubtedly provided untold benefits in the field of medical research - and today many medical centers, pharmaceutical

\footnotetext{
${ }^{30}$ Jeremy Bentham's phrase referred to in the text: "The question is not 'Can they reason?' Nor 'They can talk' but 'Can they suffer?"'.

${ }^{31}$ REGAN, Tom. Jaulas Vazias. Porto Alegre: Lugano, 2006, p. 4.

32 COHEN, Carl. REGAN, Tom. The Animal Rights Debate. Lanham: Rowman \& Littlefield Publishers, 2001, p. 127.

${ }^{33}$ REGAN, Tom. Jaulas Vazias. Porto Alegre: Lugano, 2006, p. 75.
} 
companies and research institutions still greatly rely on the use of animals to find new remedies - if there is the assumption that animals have moral rights, research must compulsorily do without this practice, regardless of the obvious damage that this position would bring to mankind. In the book The Animal Rights Debate, Regan states that ${ }^{34}$ :

If what we (individually or as a society) are doing with animals is not morally justifiable, we ought to stop doing it, and we ought to seek to keep others from doing it. If animals really do have rights, those rights deserve protection, as do the rights of vulnerable humans. Laws may be adopted to forbid conduct that is now nearly universal; regulations may forbid acts and practices to which we have long been accustomed. Such laws and regulations may prove exceedingly inconvenient and very costly. But neither inconvenience nor cost can excuse us from fulfilling our obligations. I repeat for emphasis: if animals really do have moral rights, we humans have the moral duty to respect those rights.

Given the above, Regan concludes that the current issue is strongly practical and that has nothing to do with animal welfare. According to the author, it's the experiments for the sake of human health, above all other animal exploitation by humans, which will force us to thoroughly think about animal rights.

\section{CONCLUSION}

As an instrument to pursue the satisfaction of self-interest, humans often seek to interpret ethics as for their own benefit. NACONECY ${ }^{35}$ describes what can be understood as true ethics:

Ethics is not about the "positive action for the desired result", the "good for something" (but the "positive action in itself," the "good in itself").

Ethics should not be confused with the norm of law.

\footnotetext{
34 COHEN, Carl. REGAN, Tom. The Animal Rights Debate. Lanham: Rowman \& Littlefield Publishers, 2001, p. 6.

35 NACONECY, Carlos. Ética e Animais: um guia de argumentação filosófica. Porto Alegre: EDIPUCRS, 2006. p.33.
} 
Ethics is not a simple list of ad hoc rules.

Ethics is not just a meeting of sundry intuitions.

Ethics is not a simple reformulation of moral convictions in a sophisticated language (but a justification of them).

Ethics does not only repeat the same moral judgments (but should be able to produce new). ${ }^{36}$

The search for this interpretation favorable to humans, or the positioning of other interests before the ones of non-human animals, contributes to the use of the latter as resources in a systematic manner in many fields, always as to meet human needs. The word "use" already reflects the objectification of animals, which unfortunately is still strongly rooted in our society, leading to a picture of significant damage.

The design at the base of such "use" is the idea that our moral obligations are intended as only directed to other humans (HORTA, 2009). Given these statements, it is possible to affirm that the majority of human beings hold a position of superiority with respect to animals of other species.

However, this position according to which humans hold the position of the superior or most developed specie, at the same time, definitely entails a series of responsibilities we are merely taking, including consideration we owe to other lives. These responsibilities, especially when it comes to animals, are not taken satisfactorily. Further, with regard to this perspective, it is noteworthy to underline that many of the claims that had been employed in order to use

\footnotetext{
${ }^{36}$ Translation by the author. Original text in Portuguese: A Ética não trata da "ação boa para um fim desejado", o "bom para algo", (mas da "ação boa por si mesma", o "bom por si mesmo"). A Ética não se confunde com as normas do direito. A Ética não é uma simples lista de regras ad hoc. A Ética não é uma mera reunião de intuições avulsas. A Ética não é uma simples reformulação de convicções morais numa linguagem sofisticada (mas uma justificação delas). A Ética não apenas repete os mesmos juízos morais (mas deve ser capaz de produzir novos).
} 
animals in a way that was convenient to humans, were annihilated after the Cambridge Declaration.

On July 7, 2012, the University of Cambridge (UK) held a conference entitled Francis Crick Memorial Conference, on the topic "Consciousness in Human and Non-Human Animals", where the neural bases of consciousness in human and non-human animals were addressed. Among the 13 scientists who lectured, there were Christof Koch, Stephen Hawking and Philip Low, among other doctors from important institutions such as Caltech, MIT (Massachusetts Institute of Technology) and the Max Planck Institute. The result of this conference was to draw up a statement, where 25 highly regarded researchers admitted that animals do have consciousness, including birds, monkeys, elephants, octopuses, dogs, dolphins etc., as it was recognized that the brain signals of these animals were similar to those of humans. In the words of PHILIP LOW ${ }^{37}$ :

Evidence demonstrates that humans are not the only ones to show mental states, feelings, intentional actions and intelligence; as scientists, we felt we had a professional and moral duty to report these observations to the public. It's an inconvenient truth: it was always easy to say that animals have no conscience. Now we have a group of respected neuro-scientists who study the phenomenon of consciousness, animal behaviour, the neural network, anatomy and genetics of the brain. You can no longer say that we did not know. This is a delicate matter. Our role as scientists is not what society should do, but we make public what we found. Society will now have a discussion about what is happening and may decide to formulate new laws, more research to understand the consciousness of the animal or somehow protect them. Our role is to provide information.

The insertion of such a finding in the academic and scientific community represents a major step as regards the arguments used in favor of animal protection. Thanks to its sound foundations and to the names of renowned scientists, this finding in the field of neuroscience can no longer be rejected or denied. This leads us to believe that a new ethic reflection regarding the moral

\footnotetext{
37 LOW, Philip. The Cambridge Declaration on Consciousness. Available at: $<$ http://fcmconference.org/img/CambridgeDeclarationOnConsciousness.pdf.> Accessed on: 05/05/2014.
} 
value of animals could emerge and involve a great part of society if all these scientific data (which affirm that we, humans, are not the only living being that have the capacity to feel, learn and build social relations) were diffused and addressed in a satisfactory way.

Many still believe that only science, the one of the main institutions of global studies, can prove all we can already see and feel with our own eyes or discover through very superficial studies: the existence of consciousness and sentience in many animals. It is undeniable that when we see the way in which animals live their lives, the way they care for their offspring and their own interests, always trying to survive in this world that already seems to have no room for them, touches us as human beings. Deep down, even the misbeliever, will always know that these beings have as much right to live well in this world as we do.

Translation by Chiara Bellone de Grecis ${ }^{38}$

\footnotetext{
${ }^{38}$ Graduated in Political Sciences, bachelor degree, and in a Master in International Relations, both obtained at the LUISS Guido Carli University in Rome(Italy). Currently student of the Master in Animal Law and Society at the Autonomous University of Barcelona (Spain).
} 